\title{
Long-term follow-up in sacroiliac joint pain patients treated with radiofrequency ablative therapy
}

\author{
Seguimento longo em pacientes com sacroileíte submetidos a terapia de radiofrequência \\ ablativa
}

Flávio Ramalho Romero, Roberto Bezerra Vital, Marco Antônio Zanini, Luis Gustavo Ducati, Roberto

Colichio Gabarra

\begin{abstract}
Sacroiliac joint (SIJ) pain is responsible for up to $40 \%$ of all cases of lumbar back pain. Objective: Report the long-term efficacy of radiofrequency denervation for sacroiliac joint pain at six, twelve and eighteen months. Method: Third-two adults' patients with sacroiliac join pain diagnosis were included for a prospective study. Primary outcome measure was pain intensity on the Numeric Rating Scale (NRS). Secondary outcome measure was Patient Global Impression of Change Scale (PGIC). Results: Short-term pain relief was observed, with the mean NRS pain score decreasing from $7.7 \pm 1.8$ at baseline to $2.8 \pm 1.2$ at one month and to $3.1 \pm 1.9$ at six months post-procedure ( $p<0.001$ ). Long-term pain relief was sustained at twelve and eighteen months post-procedure, with NRS pain remaining at $3.4 \pm 2.1$ and $4.0 \pm 2.7$, respectively. Conclusion: Radiofrequency denervation of the SIJ can significantly reduce pain in selected patients with sacroiliac syndrome.
\end{abstract}

Keywords: sacroiliac joint pain, radiofrequency, numeric rating scale, patient global impression of change scale.

\section{RESUMO}

A Sacroileíte pode ser responsável por até $40 \%$ dos casos de dor lombar crônica. Objetivo: Análise da eficácia da denervação por radiofrequência na articulação sacro-ilíaca em seis, doze e dezoito meses. Método: Trinta e dois pacientes com diagnóstico de sacroileíte foram incluídos em estudo prospectivo. O prognóstico primário foi avaliado pela escala visual analógico (NRS). O prognóstico secundário foi avaliado pela escala de impressão global de mudança pelo paciente (PGIC). Resultados: Melhora a curto prazo da dor foi observada, com redução media na NRS de 7,7 \pm 1,8 para 2,8 \pm 1,2 após 1 mês e para 3,1 \pm 1,9 em 6 meses do procedimento ( $p<0,001)$. Após 12 e 18 meses, o NRS manteve-se 3,4 \pm 2,1 e 4,0 \pm 2,7, respectivamente. Conclusão: A denervação da articulação sacro-ilíaca por radiofrequência pode reduzir significativamente a dor em pacientes com sacroileíte.

Palavras-chave: sacroileíte, radiofrequência, escala visual analógica, escala de impressão global de mudança do paciente.

Low back pain is reported in $70 \%-85 \%$ of population, with sacroiliac joint pain accounting for up to $40 \%$ of all cases ${ }^{1}$. Sacroiliac joint pain, an inflammatory condition of sacroiliac join (SIJ), can cause lower back pain, extended down for one or both legs, often aggravated by prolonged standing or by stair climbing ${ }^{2,3,4,5}$. Conservative management includes manual medicine techniques, pelvic stabilization exercises to allow dynamic postural control, and muscle balancing of the trunk and lower extremities. Interventional treatments include sacroiliac joint, intra-articular joint injections, radiofrequency neurotomy, cryotherapy, and surgical treatment. Although all of these methods, pain relief is a challenger in many cases ${ }^{4,5,6}$.

Radiofrequency denervation is a percutaneous procedure that use radiofrequency thermal energy to interrupts nociceptive signals, ablating the sensory nerve fibers of the sacroiliac joint. Innervation of the sacroiliac joint is associated with S1-S3 and the L4-L5 dorsal rami innervate the posterior sacroiliac joint. The lateral branches from S1-S3 emerge from the posterior sacral foramina and travel in a variable pattern to the sacroiliac joint. The purpose of this study was report the long-term efficacy of radiofrequency denervation for sacroiliac joint pain at six, twelve and eighteen months $\mathrm{s}^{7,8,9,10,11,12,13}$.

Universidade Estadual Paulista, Hospital de Clínicas, Faculdade de Medicina de Botucatu, Divisão de Neurocirurgia, Botucatu SP, Brazil.

Correspondence: Flávio Ramalho Romero; Departamento de Neurologia, Psiquiatria e Psicologia; Distrito de Rubião Júnior, s/n; $18618-970$ Botucatu SP, Brasil;

E-mail: frromero@ig.com.br

Conflict of interest: There is no conflict of interest to declare.

Received 25 November 2014; Received in final form 28 December 2014; Accepted 19 January 2015. 


\section{METHOD}

Between November 2010 and January 2013, 32 patients with diagnosis of sacroiliac joint pain due to degenerative spinal disease were considered for a prospective longitudinal cohort study. The inclusion criteria were: predominant chronic axial low lumbar pain for more than six months; signs and symptoms of sacroiliac joint pain on physical examination; failure to achieve adequate pain relief with physical therapy or pharmacotherapy; and single positive diagnostic intra-articular sacroiliac joint injection using $3 \mathrm{~mL}$ of $0.25 \%$ bupivacaine and $20 \mathrm{mg}$ methylprednisolone acetate with more than $50 \%$ pain relief for at least six hours after the procedure.

Radiofrequency denervation was performed as an ambulatory surgical procedure using superficial local anesthesia and intravenous sedation when necessary. Intravenous access was established in the preoperative area. Pulse oximetry and automated blood pressure monitoring were used. The low back and buttock area was cleaned with betadine solution and draped in a standard sterile fashion with towels. Using an anterior-posterior fluoroscopic slight oblique view S1, S2, and S3 posterior sacral foramina apertures were identified and appropriate skin starting positions were infiltrated with $3 \mathrm{~mL}$ of $1 \%$ lydocaine (Figure). Radiofrequency introducer needle was inserted under fluoroscopic images in the point between sacral foramen and SIJ, until the introducer tip touched the bony surface of the sacrum. The needle tip was positioned to be approximately $10 \mathrm{~mm}$ from the lateral edge of the posterior sacral foramina aperture. Lateral views were taken to ensure proper depth of insertion. The stylet was then withdrawn from the introducer, and the 18-gauge radiofrequency probe was fully inserted into the introducer such that the probe tip was superficially suspended approximately $2 \mathrm{~mm}$ off the sacral bony surface. At each of the respective target positions, impedance within the range of 200-500 ohms and baseline temperature readings were obtained. Once the position was verified, $1 \mathrm{~mL}$ of $0.25 \%$ bupivacaine was injected at each lesion site, and if necessary, sedation was performed.
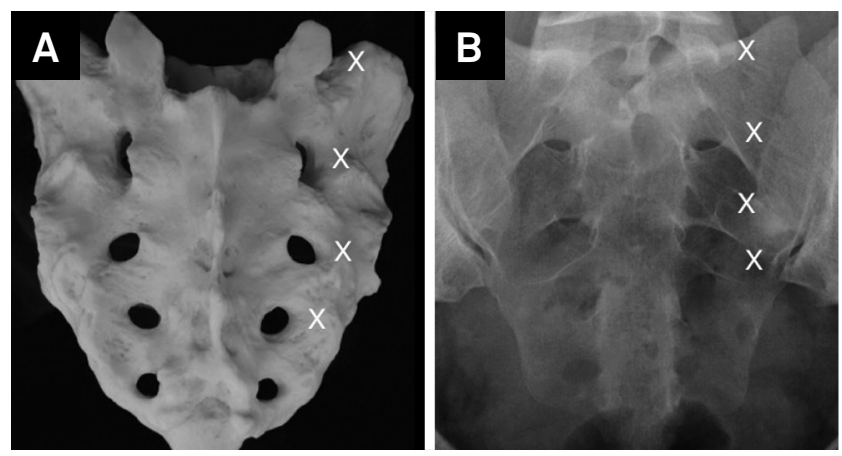

Figure. Sacral specimen (A) and sacral X ray (B) showing the point where needle tip is positioned, approximately $10 \mathrm{~mm}$ from the lateral edge of the posterior sacral foramina aperture and in the dorsal rami of $L 5(X)$.
Radiofrequency lesion was then carried out at a set temperature of $80^{\circ} \mathrm{C}$ for 90 seconds in S1, S2, and S3 unilateral or bilateral depending on the case. The respective location of the left or right dorsal rami of L5 was identified using an oblique fluoroscopic view. Sensory stimulation was obtained at less than $50 \mathrm{~Hz}$ and $0.5 \mathrm{~V}$ and motor stimulation at $2 \mathrm{~Hz}$ was negative up to $1.5 \mathrm{~V}$. Then, the lesion of L5 dorsal ramus was performed at $80^{\circ} \mathrm{C}$ for 90 seconds.

Primary outcome measure was pain intensity on the Numeric Rating Scale (NRS, with 0 being "no pain" and 10 being the "worst possible pain"). Secondary outcome measure was Patient Global Impression of Change scale (PGIC), a seven-point scale ranging from "very much improved" [+3] to "no change" [0] to "very much worse" [-3]. The local ethics committee approved this study. Statistical analysis using paired t-tests was performed using the Statistical Package for the Social Sciences version 17.0 software (SPSS Inc, Chicago, IL, USA).

\section{RESULTS}

The procedure was generally well tolerated by all patients. There were 14 female and 18 male patients with mean age of $58.3 \pm 15.7$ years. Fifteen patients underwent bilateral sacroiliac joint radiofrequency denervation and seventeen underwent unilateral denervation. Short-term pain relief was observed, with the mean NRS pain score decreasing from $7.7 \pm 1.8$ at baseline to $2.8 \pm 1.2$ at one month and to $3.1 \pm 1.9$ at six months post-procedure $(\mathrm{p}<0.001)$. Long-term pain relief was sustained at twelve and eighteen months post-procedure, with NRS pain remaining at $3.4 \pm 2.1$ and $4.0 \pm 2.7$, respectively. Patient baseline characteristics are presented in Table 1, and outcome measures are presented in Table 2.

No complications or side effects were observed in any of the patients. In general, patients felt that pain was improved, and the mean PGIC score was $1.3 \pm 1.1$. Global perceived effect (GPE) for patient satisfaction was positive in 27 of 32 patients. Three patients without pain relief after the procedure had prescribed oral opioids and GABA analog with improve in their pain. Two patients had failed back surgery syndrome and bilateral sacroiliac joint pain, and also underwent bilateral radiofrequency denervation without success.

\section{DISCUSSION}

SIJ connect spine to pelvis, providing shock absorption for spine through a gliding-type motion. Movement of this joint is minimal, about two to four millimeters with weight bearing activity ${ }^{2,3,4}$. Many conditions can cause sacroiliac joint pain, including heavy lifting, traumatic injury or sudden impact, spondyloarthropathies, degenerative arthritis, pregnancy, infection of the sacroiliac joint (brucellosis) $)^{1,2,3}$. 


\begin{tabular}{|c|c|c|c|c|c|c|c|c|c|}
\hline Case & Age & Gender & SIJ involved & $\begin{array}{c}\text { Pre-op } \\
\text { NRS }\end{array}$ & 1-m NRS & 6-m NRS & 12-m NRS & 18-m NRS & PGIC \\
\hline 1 & 58 & $M$ & Right & 7 & 3 & 4 & 4 & 4 & 1 \\
\hline 2 & 62 & $\mathrm{~F}$ & Bilateral & 8 & 2 & 3 & 4 & 4 & 2 \\
\hline 3 & 49 & $\mathrm{~F}$ & Left & 9 & 3 & 3 & 4 & 5 & 1 \\
\hline 4 & 72 & M & Right & 6 & 2 & 2 & 2 & 3 & 2 \\
\hline 5 & 67 & $\mathrm{~F}$ & Bilateral & 8 & 1 & 2 & 1 & 2 & 3 \\
\hline 6 & 56 & M & Right & 9 & 2 & 3 & 3 & 4 & 1 \\
\hline 7 & 71 & M & Bilateral & 8 & 1 & 3 & 2 & 3 & 2 \\
\hline 8 & 59 & M & Bilateral & 6 & 2 & 2 & 2 & 3 & 1 \\
\hline 9 & 54 & $\mathrm{~F}$ & Right & 7 & 3 & 3 & 3 & 4 & 0 \\
\hline 10 & 63 & M & Bilateral & 8 & 5 & 4 & 5 & 5 & 2 \\
\hline 11 & 62 & $M$ & Left & 7 & 4 & 4 & 4 & 5 & -1 \\
\hline 12 & 70 & $F$ & Right & 9 & 5 & 5 & 5 & 5 & 1 \\
\hline 13 & 53 & M & Bilateral & 10 & 3 & 4 & 5 & 5 & 1 \\
\hline 14 & 68 & $\mathrm{~F}$ & Right & 6 & 2 & 3 & 3 & 4 & 2 \\
\hline 15 & 61 & F & Bilateral & 8 & 4 & 4 & 4 & 4 & 1 \\
\hline 16 & 68 & $M$ & Bilateral & 7 & 3 & 3 & 3 & 5 & -1 \\
\hline 17 & 46 & $\mathrm{~F}$ & Left & 9 & 5 & 4 & 4 & 5 & -1 \\
\hline 18 & 52 & M & Bilateral & 7 & 4 & 4 & 4 & 4 & 1 \\
\hline 19 & 59 & M & Right & 8 & 4 & 3 & 4 & 4 & 1 \\
\hline 20 & 51 & $M$ & Left & 6 & 3 & 3 & 4 & 5 & 1 \\
\hline 21 & 49 & M & Right & 8 & 2 & 2 & 3 & 3 & 3 \\
\hline 22 & 61 & $F$ & Bilateral & 9 & 1 & 1 & 2 & 3 & 3 \\
\hline 23 & 63 & M & Bilateral & 10 & 5 & 5 & 5 & 4 & 1 \\
\hline 24 & 48 & F & Left & 6 & 1 & 1 & 2 & 3 & 0 \\
\hline 25 & 56 & $\mathrm{~F}$ & Right & 7 & 4 & 4 & 4 & 4 & 1 \\
\hline 26 & 52 & M & Bilateral & 8 & 4 & 4 & 5 & 4 & 1 \\
\hline 27 & 67 & $\mathrm{~F}$ & Left & 8 & 3 & 3 & 4 & 5 & 1 \\
\hline 28 & 51 & $F$ & Bilateral & 7 & 4 & 5 & 5 & 4 & 1 \\
\hline 29 & 53 & $M$ & Right & 9 & 1 & 2 & 2 & 4 & 3 \\
\hline 30 & 63 & F & Bilateral & 9 & 1 & 2 & 2 & 3 & 3 \\
\hline 31 & 42 & M & Bilateral & 7 & 2 & 2 & 2 & 4 & 2 \\
\hline 32 & 61 & $\mathrm{M}$ & Right & 8 & 2 & 3 & 3 & 5 & 1 \\
\hline
\end{tabular}

M: male; F: female; SIJ: sacroiliac joint; Pre-op: preoperative; m: months; NRS: numeric rate scale of pain; PGIC: Patient Global Impression of Change scale. Age in years.

International Association for the Study of Pain diagnostic criteria for sacroiliac syndrome include: pain in the region of the sacroiliac joint with possible radiation to the groin, medial buttocks, and posterior thigh; reproduction of pain by physical examination techniques that stress the joint; elimination of pain by intra-articular injection of local anesthetic; and an ostensibly morphologically normal joint without demonstrable pathognomonic radiographic abnormalities ${ }^{3,4,5,6}$.

SIJ is a true diarthrodial joint with unique characteristics. Because its fibrocartilage in addition to hyaline cartilage, there is discontinuity of the posterior capsule, and articular surfaces have many ridges and depressions ${ }^{5}$. SIJ is well innervated being a source of low back pain and referred pain in the lower extremity. Histological analysis of the sacroiliac joint has verified the presence of nerve fibers within the joint capsule and adjoining ligaments. It has been variously described that the sacroiliac joint receives its innervation from the ventral rami of L4 and L5, the superior gluteal nerve, and the
Table 2. Outcome measures.

\begin{tabular}{lccc}
\hline NRS of pain & Mean & Standard deviation & p value \\
\hline Pre-operative & 7.7 & 1.8 & $<0.001$ \\
After 1 month & 2.8 & 1.2 & $<0.001$ \\
After 6 months & 3.1 & 1.9 & $<0.001$ \\
After 12 months & 3.4 & 2.1 & $<0.001$ \\
After 18 months & 4.0 & 2.7 & $<0.001$ \\
\hline NRS:
\end{tabular}

NRS: numeric rate scale of pain.

dorsal rami of L5, S1, and S2, or that it is almost exclusively derived from the sacral dorsal rami ${ }^{57,12,13,14,15,16,17}$.

Our results in 32 patients demonstrated the long-term radiofrequency denervation efficacy of sacroiliac joint pain management. No serious complications or side effects were observed in our patients. Almost seventy-five percent of the patients showed a clinically relevant degree of pain relief, with at least a three-point reduction in NRS for pain, representing a statistically significant reduction in mean pain intensity 
scores. PGIC for symptom improvement was favorable and GPE for patient satisfaction was positive in $78 \%$ of patients.

Many methods of radiofrequency denervation have been reported in the literature, with discrepancies between success rates that may be associated to the different techniques used or to anatomic variation of the sensory fibers innervating the sacroiliac joint ${ }^{18,19,20}$. Yin et al. reported an anatomic locations of the lateral sacral branches exited the sacral foramen between the 2 o'clock and 6 o'clock positions on the right, and between the 6 o'clock and 10 o'clock positions on the left, with great variation. In addition, the number, location, and path of the lateral branches to the sacroiliac joint were not consistent ${ }^{9}$.

In a pilot study, Cohen and Abdi used radiofrequency denervation at the medial branch of L4, the dorsal rami of L5, and the lateral branches of S1-S3 to treat patients with sacroiliac joint pain. Eight of nine patients had more than $50 \%$ pain relief that lasted for more than nine months ${ }^{16}$. Ferrante et al. reported use of radiofrequency denervation with bipolar electrodes for thermoablation along the sacroiliac joint line. In their study, $36.4 \%$ of patients had a $50 \%$ reduction in pain for a period of at least six months ${ }^{11}$. Vallejo et al. used pulsed radiofrequency denervation of the medial branch of L4, posterior ramus of L5, and lateral branches of S1 and S2. Seventy-three percent of their patients had more than $50 \%$ pain relief for $6-32$ weeks $^{13}$. Ho et al. demonstrated the efficacy of cooled radiofrequency in 2 years to treat twenty patients with sacroiliac joint pain ${ }^{21}$. But long follow-up with great casuistic papers were not founded in literature.

Besides our study was consistent with other published reports of radiofrequency denervation for the sacroiliac joint, there are some limitations regarding it was a prospective study with no placebo-control or sham-control group. There was also no comparison with other treatments for sacroiliac joint pain.

In conclusion, this study suggests that ratio frequency denervation of the SIJ can significantly reduce pain in selected patients with sacroiliac syndrome, being an effective treatment for some patients.

\section{References}

1. Freburger JK, Holmes GM, Agans RP, et al. The rising prevalence of chronic low back pain. Arch Intern Med. 2009;169(3):251-8. http://dx.doi.org/10.1001/archinternmed.2008.543

2. Schwarzer AC, Aprill CN, Bogduk N. The sacroiliac joint in chronic low back pain. Spine. 1995;20(1):31-7.

3. Merskey H, Bogduk N. Classification of chronic pain: descriptions of chronic pain syndrome and definitions of pain terms. 2nd ed. Seattle: IASP; 1993.

4. Weiner DK, Kim YS, Bonino P, Wang T. Low back pain in older adults: are we utilizing healthcare resources wisely? Pain Med. 2006;7(2):143-50. http://dx.doi.org/10.1111/j.1526-4637.2006.00112.x

5. Cohen SP. Sacroiliac joint pain: a comprehensive review of anatomy, diagnosis, and treatment. Anesth Analg. 2005;101 (5):1440-53. http://dx.doi.org/10.1213/01.ANE.0000180831.60169.EA

6. Dougados M, Linden S, Juhlin R, Huitfeldt B, Amor B, Calin A et al. The European Spondylarthropathy Study Group preliminary criteria for the classification of spondylarthropathy. Arthritis Rheum. 1991;34(10):1218-27. http://dx.doi.org/10.1002/art.1780341003

7. Burnham RS, Yasui Y. An alternate method of radiofrequency neurotomy of the sacroiliac joint: a pilot study of the effect on pain, function, and satisfaction. Reg Anesth Pain Med. 2007;32(1):12-9.

8. Weksler N, Velan GJ, Semionov M, Gurevitch B, Klein M, Rozentsveig $V$ et al. The role of sacroiliac joint dysfunction in the genesis of low back pain: the obvious is not always right. Arch Orthop Trauma Surg. 2007;127(10):885-8. http://dx.doi.org/10.1007/s00402-007-0420-x

9. Yin W, Willard F, Carreiro J, Dreyfuss P. Sensory stimulation-guided sacroiliac joint radiofrequency neurotomy: technique based on neuroanatomy of the dorsal sacral plexus. Spine. 2003;28(20):2419-25. http://dx.doi.org/10.1097/01.BRS.0000085360.03758.C3

10. Patel N, Gross A, Brown L, Gekht G. A randomized, placebocontrolled study to assess the efficacy of lateral branch neurotomy for chronic sacroiliac joint pain. Pain Med. 2012;13(3):383-98. http://dx.doi.org/10.1111/j.1526-4637.2012.01328.x

11. Ferrante FM, King LF, Roche EA, Kim PS, Aranda M, Delaney LR et al. Radiofrequency sacroiliac joint denervation for sacroiliac syndrome. Reg Anesth Pain Med. 2001;26(2):137-42. http://dx.doi.org/10.1097/00115550-200103000-00008
12. Farrar JT, Young JP, Jr, LaMoreaux L, Werth JL, Poole RM. Clinical importance of changes in chronic pain intensity measured on an 11-point numerical pain rating scale. Pain. 2001;94(2):149-58. http://dx.doi.org/10.1016/S0304-3959(01)00349-9

13. Vallejo R, Benyamin RM, Kramer J, Stanton G, Joseph NJ. Pulsed radiofrequency denervation for the treatment of sacroiliac joint syndrome. Pain Med. 2006;7(5):429-34. http://dx.doi.org/10.1111/j.1526-4637.2006.00143.x

14. Haemmerich D, Chachati L, Wright AS, Mahvi DM, Lee Jr FT, Webster JG et al. Hepatic radiofrequency ablation with internally cooled probes: effect of coolant temperature on lesion size. IEEE Trans Biomed Eng. 2003;50(4):493-500. http://dx.doi.org/10.1109/TBME.2003.809488

15. Lorentzen T. A cooled needle electrode for radiofrequency tissue ablation: thermodynamic aspects of improved performance compared with conventional needle design. Acad Radiol. 1996;3(7):556-63. http://dx.doi.org/10.1016/S1076-6332(96)80219-4

16. Cohen SP, Abdi S. Lateral branch blocks as a treatment for sacroiliac joint pain: a pilot study. Reg Anesth Pain Med. 2003;28(2):113-9.

17. Cohen SP, Hurley RW, Buckenmaier CC, 3rd, Kurihara C, Morlando B, Dragovich A. Randomized placebo-controlled study evaluating lateral branch radiofrequency denervation for sacroiliac joint pain. Anesthesiology. 2008;109(2):279-88. http://dx.doi.org/10.1097/ALN.0b013e31817f4c7c

18. Stelzer W, Aiglesberger M, Stelzer D, Stelzer V. Use of cooled radiofrequency lateral branch neurotomy for the treatment of sacroiliac joint-mediated low back pain: a large case series. Pain Med. 2013;14(1):29-35. http://dx.doi.org/10.1111/pme.12014

19. Pino CA, Hoeft MA, Hofsees C, Rathmell JP. Morphologic analysis of bipolar radiofrequency lesions: implications for treatment of the sacroiliac joint. Reg Anesth Pain Med. 2005;30(4):335-8.

20. Kapural L, Nageeb F, Kapural M, Cata JP, Narouze S, Mekhail N. Cooled radiofrequency system for the treatment of chronic pain from sacroiliitis: the first case-series. Pain Pract. 2008;8(5):348-54. http://dx.doi.org/10.1111/j.1533-2500.2008.00231.x

21. Ho KY, Hadi MA, Pasutharnchat K, Tan KH. Cooled radiofrequency denervation for treatment of sacroiliac joint pain: two-year results from 20 cases. J Pain Res. 2013; 6: 505-11. http://dx.doi.org/10.2147/JPR.S46827 